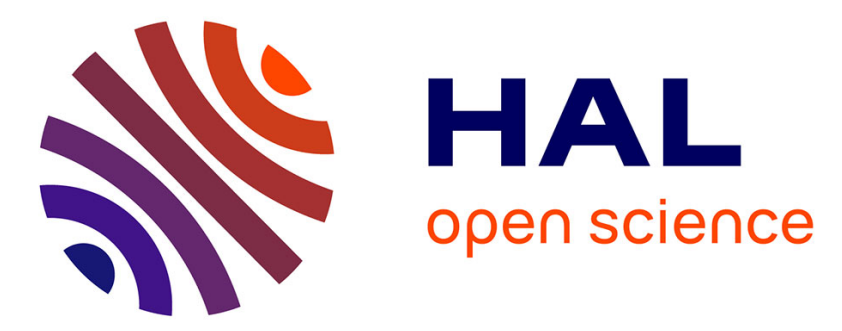

\title{
White Peach Scale, Pseudaulacaspis pentagona (Targ.) (Hemiptera: Diaspididae), is affected by host plant variety in a blackcurrant orchard
} Ruddy Kuzmin, Marie-Charlotte Anstett, Philippe Louapre

\section{- To cite this version:}

Ruddy Kuzmin, Marie-Charlotte Anstett, Philippe Louapre. White Peach Scale, Pseudaulacaspis pentagona (Targ.) (Hemiptera: Diaspididae), is affected by host plant variety in a blackcurrant orchard. Entomologia Generalis, 2020, 40 (4), pp.377-383. 10.1127/entomologia/2020/0813 . hal03097550

\author{
HAL Id: hal-03097550 \\ https://hal.science/hal-03097550
}

Submitted on 6 Jan 2021

HAL is a multi-disciplinary open access archive for the deposit and dissemination of scientific research documents, whether they are published or not. The documents may come from teaching and research institutions in France or abroad, or from public or private research centers.
L'archive ouverte pluridisciplinaire HAL, est destinée au dépôt et à la diffusion de documents scientifiques de niveau recherche, publiés ou non, émanant des établissements d'enseignement et de recherche français ou étrangers, des laboratoires publics ou privés. 
1 White peach scale Pseudaulacaspis pentagona (Targ.) (Hemiptera: Diaspididae) is

2 affected by host plant variety in a blackcurrant orchard

3

4 Kuzmin Ruddy ${ }^{1}$, Anstett Marie-Charlotte ${ }^{1}$, Louâpre Philippe ${ }^{1^{*}}$

5

$6 \quad{ }^{1}$ Biogéosciences, UMR 6282 CNRS, Université Bourgogne Franche-Comté, 6 Boulevard 7 Gabriel, 21000 Dijon, France.

8

9 *Correspondence: Philippe Louâpre, Biogéosciences, UMR 6282 CNRS, Université

10 Bourgogne Franche-Comté, 6 Boulevard Gabriel, 21000 Dijon, France.

11 E-mail address: philippe.louapre@u-bourgogne.fr 
12

13

14

\section{Abstract}

The White Peach Scale (WPS) Pseudaulacaspis pentagona (Homoptera: Diaspididae) is one of the most damaging armored scale insects as it is a pest of various crops, including ornamental plants and fruit trees. In France, P. pentagona has become one of the main threats towards blackcurrants (Ribes nigrum L.), especially in Burgundy, the Loire Valley and the Rhône-Alpes where the cultivation of blackcurrants is not only an emblematic and cultural activity but also an important economic one. We determined the direct effect of blackcurrant varieties on the infestation rate, female's size and parasitism of $P$. pentagona. Our study was conducted in a Burgundy (France) natural population of $P$. pentagona developing on two blackcurrant varieties 'Noir de Bourgogne' and 'Royal de Naples'. This field study showed that females WPS feeding on 'Noir de Bourgogne' were more numerous, had a larger body, a larger shield, and were less parasitized compared to females feeding on 'Royal de Naples' at the same site. However, the high scale density and the low parasitism rate found overall on the two varieties question the potential gain for a possible pest management based on the change of the varieties used in blackcurrant orchards.

\section{Keywords}

Trophic interaction, parasitism, WPS, performance, blackcurrant

\section{Compliance with ethical standards}

Conflict of interest - The authors declare that they have no conflict of interest.

3 Ethical note - All experiments complied with French laws on animal experimentation. 


\section{Introduction}

White Peach Scale (WPS), Pseudaulacaspis pentagona Targioni Tozzetti (Homoptera:

Diaspididae), is a cosmopolitan pest originating in Eastern Asia. It is now present in 110 countries on every continent, from tropical to temperate regions (García Morales et al. 2016). Due to its wide host plant spectra (reported on 221 host plant genera), P. pentagona is one of the most damaging armored scale pests for various crops, including ornamental plants and fruit trees (Bennett 1956; Bennett and Brown 1958; Hanks and Denno 1993b; Kreiter and Marro 1997; Kreiter et al. 2002; García-Morales et al. 2016). In France, it has become one of the main threats to blackcurrant cultivation (Ribes nigrum L.), especially in Burgundy, the Loire valley and the Rhône-Alpes regions where blackcurrant production is an emblematic activity as well as an important economic activity. In the years following infestation, blackcurrants experience a decrease in plant vigor, defoliation and the subsequent death of infested plants and orchards - probably due to intense sap collection by $P$. pentagona when female density is high (Yasuda 1979; Dalstein et al. 2016).

Using several varieties of a species in the same agricultural plot may improve crop productivity and quality, or may reduce vulnerability to disease and environmental fluctuations (Jarvis et al. 2008; Kotowska et al. 2010). By contrast, the vast majority of blackcurrant cultivators follow a monoculture regime system with usually a very few varieties per orchard. Moreover, farmers commonly use cuttings from a single clone for the whole orchard, which results in low genetic diversity. In Burgundy, the variety 'Noir de Bourgogne' (NB) is mostly planted in association with the variety 'Royal de Naples' (RN), with a usual ratio of about 5 to 1 . NB produces berries with a very high organoleptic quality, but requires cross-pollination with $\mathrm{RN}$ for a good yield. $\mathrm{RN}$ was selected as a pollen donor since it crosses nicely with NB without affecting NB's organoleptic properties. These two varieties have different phenological, horticultural and nutritional qualities (Giongo et al. 2008; personal 
observation). NB is richer in aroma than $\mathrm{RN}$, contains different essential oils and has a slightly delayed phenology (Kerslake et al. 1989; Le Quere and Latrasse 1990; Giongo et al. 2008; personal observation).

Herbivorous pests such as scale insects may be influenced by the host plant species and/or variety, which may results in different life histories through phenotypic plasticity, or in some cases, local adaptations depending on the host plant they feed on. For example, there is abundant evidence that differences between host plants (between or within species) affect morphology, longevity, fecundity, and resistance against the natural enemies of phytophagous insects (Awmack and Leather 2002; Moreau et al. 2017; Giron et al. 2018). This is particularly expected in scale insects such as $P$. pentagona because of their sedentary lifestyle (Gullan and Kosztarab 1997). For example, P. pentagona females exhibit typical local adaptations to their host plant, and individuals raised on their native host plant survive longer than those raised on a non-native host plant (Hanks and Denno 1993a, b).

The aim of this study was to determine the direct effect of blackcurrant variety on the infestation rate, size and parasitism of $P$. pentagona, in order to compare the pressure exerted by this pest on blackcurrant orchards. These data are crucial in blackcurrant orchards because a specific phytophagous pressure exerted on the variety of economic interest would change blackcurrant cultivation. Indeed, an hypothetic infestation rate higher one variety than on another should lead growers to modify the variety of economic interest, or the variety used as pollen donor.

The study was conducted with a natural population of $P$. pentagona collected in Burgundy (France) on NB and RN varieties. We specifically focused on females because they feed on blackcurrant plants from the stage following crawlers to their death, making them more sensitive to plant variety in comparison with males (non-feeding adult stage). Females are thus the most critical sex damages blackcurrant orchards. 
85

\section{Materials and methods}

\section{Field sampling}

In April 2018, we collected overwintering P. pentagona females from blackcurrant (Ribes

nigrum L.) in Burgundy, France. In order to reduce geographical and climatic effects, individuals were sampled in a three-hectare blackcurrant orchard, with the two varieties planted alternately (one shrub of RN every five shrubs of NB) in Marey-Les-Fussey, France $\left(\mathrm{N}-47^{\circ} 07^{\prime} 30^{\prime \prime}, \mathrm{E}-4^{\circ} 51^{\prime} 01^{\prime \prime}\right)$. For each variety, one branch $(45-136 \mathrm{~cm}$ in length), cut at the base of each shrub, was collected from 20 shrubs, following the following stratified sampling procedure: 12 branches were collected from shrubs randomly selected within the first and the last rows of crops, and 8 branches were collected from shrubs randomly chosen within the three central rows of the orchards. These branches were put in a flower vase with fresh tap water, and maintained in a climate room at $22{ }^{\circ} \mathrm{C}$ and under a natural photoperiod.

Observations were made within a maximum period of 2 days after cutting to avoid dehydration of the samples. A total of 40 branches were collected within 4 days of sampling. For each branch, observations were made on two cuttings $(\mathrm{h}=2 \mathrm{~cm}$ in length) taken at $10 \mathrm{~cm}$ (basal section) and $25 \mathrm{~cm}$ (middle section) from the base of the cutting in order to control for factors other than blackcurrant variety (e.g. microclimatic condition, plant tissue quality). In order to calculate densities (number of individuals / surface of the cutting), the diameters of each cutting ( $\mathrm{R}$ at the top and $\mathrm{r}$ at the bottom) were recorded. The surface $\mathrm{S}$ of each cutting was approximated by the lateral surface of a truncated cone (without the sections) with the following equation:

$$
\mathrm{S}=\pi \times(\mathrm{R}+\mathrm{r}) \times \sqrt{\mathrm{h}^{2}+(\mathrm{R}-\mathrm{r})^{2}}
$$

A total of 80 branch segments were collected and inspected. 


\section{Density of shields and alive females, proportion of parasitized scales}

110 Females WPS develop under protective shields that may accumulate on several layers year

111 after year. Some young larvae stay and secrete their shield while still under the mother shield

112 instead of migrating along the branch, thus leading to shield overlapping since dead mothers

113 decay and disappear. We estimated the density of females' shields as the number of apparent

114 overlapping shields divided by the surface of the cutting. The density of living females was

115 estimated by carefully lifting each shield with fine pliers under a stereomicroscope (Nikon

116 SMZ1500, X20) to count only the females alive when collected from the field (orange-

117 colored and turgescent, without any indication of parasitism). The density of scales and living

118 females was estimated by dividing the number of items by the surface of each cutting. The

119 proportion of parasitized scales was estimated by dividing the number of scales exhibiting

120 indications of parasitism (e.g. an emergence hole, larvae inside or outside of the female body)

121 by the total number of shields found on each cutting. This metric underestimates the

122 parasitism rate occurring at a certain time in the field, but since it is impossible to determine

123 the generation of an scale, it is not possible to estimate the accumulation of shields from

124 generation to generation makes it impossible to estimate. Indeed, the moment at which an

125 individual has been parasitized (i.e. every shield exhibiting indication of parasitism) cannot be 126 identified.

127 On the 80 branch segments collected from the two blackcurrant varieties, a total of 14,248

128 females were found and inspected for parasitism.

\section{$130 \quad$ Size of the WPS females}

131 On each of the 80 branch segments collected from the field, we measured the body size and

132 the shield surface of the first five living females found (when lifting shields) for a total of 400

133 females. We measured the first well-developed anterior segment of each insect for its width 
134 and the surface area of the shield under a stereomicroscope (Nikon SMZ1500, X20) with

135 software Image J 1.49. Unfortunately, it was not possible to estimate female fecundity

136 because eggs are continuously laid during the adult stage (Hanks and Denno 1993b).

\section{Statistical analysis}

139 All statistical tests were completed using R-CRAN (Version 3.4.3, R Core Team 2017). For

140 each cutting, we calculated (i) the density of shields, (ii) the density of alive females, and (iii)

141 the proportion of parasitized scales. These metrics were compared between the two

142 blackcurrant varieties by using analysis of variance (ANOVA) with Linear Mixed-Effects

143 models (package lme). The models included the blackcurrant varieties (NB, RN) and the

144 position of the cutting on the branch (basal, middle) as fixed factors, and branch as a random

145 factor (Pinheiro et al. 2018). When testing for differences between female mortality, we also

146 included the female density as covariate in the model in order to test for a plausible effect of

147 the density on mortality. To highlight significant differences among groups, Cohen's $d$ s with

148 their bootstrapped confidence intervals ( $\mathrm{CI}_{95 \%}, 10000$ iterations) were calculated and reported

149 (Nakagawa and Cuthill, 2007). These standardised measures of effect size allowed us to

150 quantify the overall effect of the blackcurrant variety on the measured traits. The relationship

151 between female width and shield surface was analyzed with a Linear Mixed-Effects Model,

152 with female width as a covariate, blackcurrant varieties and position of the cutting as fixed

153 factors, and branch as random factor.

\section{Results}

156 Density of shields and living females, proportion of parasitized scales

157 Blackcurrant variety influenced the density of $P$. pentagona shields: on average, the density of 158 shields was higher on NB (mean density $=28.29$ shields $\left.. \mathrm{cm}^{-2}, \mathrm{CI}_{95 \%}=[24.29 ; 32.29]\right)$ than on 
159

160

161

162

163

164

165

166

167

168

169

170

171

172

173

174

175

176

177

178

179

180

181

182

$\mathrm{RN}\left(\right.$ mean density $=15.26$ shields.cm $\left.{ }^{-2}, \mathrm{CI}_{95 \%}=[12.38 ; 18.15]\right)\left(\mathrm{F}_{1 ; 38}=34.12, \mathrm{P}<0.001 ; d=\right.$ $1.21, \mathrm{CI}_{95 \%}=[0.79 ; 1.71]$; Figure 1A). The density of living females on NB (mean density = $\left.5.33, \mathrm{CI}_{95 \%}=[4.60 ; 6.06]\right)$ was higher than on $\mathrm{RN}\left(\right.$ mean density $\left.=2.25, \mathrm{CI}_{95 \%}=[1.66 ; 2.83]\right)$ $\left(\mathrm{F}_{1 ; 38}=34.12, \mathrm{P}<0.001 ; d=1.52, \mathrm{CI}_{95 \%}=[1.08 ; 2.05] ;\right.$ Figure 1B $)$. The density of living females was positively correlated with the density of shields on the branch $(r=0.8, t=11.77$, $\mathrm{df}=78, \mathrm{p}<0.001)$. Among all shields found on the cuttings, the proportion of parasitized scales was higher on $\mathrm{RN}$ (mean proportion $=0.03, \mathrm{CI} 95 \%=[0.02 ; 0.04])$ than on $\mathrm{NB}($ mean proportion rate $\left.=0.018, \mathrm{CI}_{95 \%}=[0.01 ; 0.02]\right)\left(\mathrm{F}_{1 ; 38}=5.95, \mathrm{P}=0.02 ; d=0.6, \mathrm{CI}_{95 \%}=[0.20 ;\right.$ 1.02]; Figure 1C). Overall, NB bore 2.36 times more alive females than RN, which was associated with parasitism reduced by almost half. The position of the cutting on the branch (basal vs. middle sections) had no effect on the density of shields $\left(\mathrm{F}_{1 ; 38}=4.08, \mathrm{P}=0.05\right)$, the density of living females $\left(\mathrm{F}_{1 ; 39}=4.03, \mathrm{P}=0.05\right)$, nor on the proportion of parasitized scales $\left(\mathrm{F}_{1 ; 39}=0.98, \mathrm{P}=0.33\right)($ Figure 1$)$

\section{Female size}

The body size of $P$. pentagona females depended on which blackcurrant variety they fed on: females feeding on RN had a smaller first anterior segment (mean segment width $=0.99 \mathrm{~mm}$, $\left.\mathrm{CI}_{95 \%}=[0.97 ; 1.01]\right)$ compared to those feeding on NB (mean segment width $=1.13 \mathrm{~mm}$, $\left.\mathrm{CI}_{95 \%}=[1.11 ; 1.16]\right)\left(\mathrm{LMEM}-\mathrm{F}_{1 ; 38}=32.39, \mathrm{P}<0.001\right.$, Figure $\left.2 \mathrm{~A}\right)$. Their size was not influenced by the position of the cutting on the branch $\left(\mathrm{LMEM}-\mathrm{F}_{1 ; 335}=0.04, \mathrm{P}=0.842\right)$.

Shield surface depended on both first anterior segment width and blackcurrant variety $\left(\mathrm{LMEM}-\right.$ interaction term, $\left.\mathrm{F}_{1 ; 334}=18.66, \mathrm{P}<0.001\right)$ : shield surface increased faster with first anterior segment width for females feeding on NB than for females feeding on RN (Figure 2B). 
184

185

186

187

188

189

190

191

192

193

194

195

196

197

198

199

201

202

203

204

205

\section{Discussion}

Our field study showed that females WPS feeding on 'Noir de Bourgogne' were more numerous, had a larger body size, a larger shield, and were less parasitized compared to females feeding on 'Royal de Naples' at the same site. In armored scale insects, host plant quality is a key determinant of their life history. For example, orange tree varieties influence the fecundity of two diaspidid species: Lepidosaphes beckii and Parlatoria pergandii (Boyero et al. 2007). Until now, a similar effect on fecundity has only been shown for P. pentagona between individuals developing on different host plant species. Erkiliç and Uygun (1997) showed differences in the life tables of WPS reared in the laboratory on peach, potato and squash; they demonstrated that host plant species affected longevity, development time and fecundity. Here, we demonstrated that the variety of the same host plant species, Ribes nigrum, influences $P$. pentagona performance in field conditions. Intrinsic characteristics of the blackcurrant varieties may explain the observed differences in parasitism, body and scale size of $P$. pentagona. Kerslake et al. (1989) showed that NB and RN buds have distinct chemotypes based on molecules such as, among others, $\delta$ elemene, $\gamma$-elemene, allo-aromadendrene, and two unknown sesquiterpene hydrocarbons. Some of these molecules could have a direct effect on $P$. pentagona female's size and mortality, as both varieties host a different number of females, especially living females. It is thus possible that RN resists $P$. pentagona attacks better than NB. This has already been shown for other blackcurrant varieties which are known to express different resistance levels to insect pests and fungal diseases as shown, for example, against white pine blister rust Cronartium ribicola (Pluta and Broniarek-Niemiec 2000) or the big bud mite Cecidophyopsis ribis (Łabanowska and Pluta 2010).

Intrinsic differences between the two varieties may also explain the observed different parasitism rate. This difference may indeed involve host plant nutritional quality or toxic 
defensive compounds, all impacting the size of $P$. pentagona and its vulnerability towards their natural enemies (Price et al. 1980; Inbar and Gerling 2008, Wetzel et al. 2016). For example, the effect of host plant variety on the ability of herbivores to avoid or resist parasitoids has been thoroughly studied in vineyards - providing a similar case study to blackcurrant cultivation where host plant varieties may be cultivated simultaneously in the same plot. Grape variety has a strong impact on the immune function of the grape berry moth, Eupoecilia ambiguella (Vogelweith et al. 2015), which affects the moths' propensity to be parasitized by endoparasitoids (Moreau et al. 2010; Vogelweith et al. 2013). Natural enemies (including parasitoids and predators) may thus represent a strong force that shapes the abundance and spatial distribution of $P$. pentagona in mulberry trees (Hanks and Denno 1994). Habitats hosting abundant natural enemies are those on which $P$. pentagona survival is low. It is thus possible that the two blackcurrant varieties differently attract local parasitoids, among others Encarsia spp. and Aphitys spp. (Pedata et al. 1995; Rauleder 2011, personal observations), resulting in a higher rate of parasitism on RN rather than NB.

Faced with these two varieties of different quality for $P$. pentagona, our results may suggest a specific apparent preference for NB rather than RN. However, there is no evidence in the literature of an active behavioral preference of $P$. pentagona females for a given profitable host plant, presumably because of its very limited dispersal ability at larval stage and its sedentary lifestyle when adult (Beardsley and Gonzalez 1975). Differences in chemotypes and/or phenology are thus likely to be more influential on survival and susceptibility to parasitoids of females settled on each of the two varieties, compared to unlikely different attraction/repellant levels between the blackcurrant varieties.

Our results demonstrate that NB suffers a higher pressure exerted by $P$. pentagona than RN in our experimental field, and, in addition, females infesting NB are less attacked by local parasitoids than RN. Thus, our study reveals a trend in blackcurrant cultivation, 
234 especially for NB, the variety of economic interest in Burgundy, which suffers a higher pest

235 pressure in comparison with RN. To select and to use specific plant varieties should be a

236 valuable pest management strategy which manipulates natural enemies to produce beneficial

237 long-term results (Bottrell et al. 1998). However, the very high density of P. pentagona

238 females and the low parasitism rate we found in our experimental field constrain the

239 establishment of a rapid and efficient biological control of P. pentagona. Moreover, we

240 sampled $P$. pentagona females during one year only, which limits the generalization of our

241 results to the entire blackcurrant cultivation. Future researches should test for the effect of

242 soil, agricultural practices and climatic conditions on the trend we revealed here. For example,

243 environmental temperature and precipitation pattern are key ecological factors that may affect

244 the trophic relationship between blackcurrant varieties, $P$. pentagona females and their related 245 parasitoids, as it is the case for many other biological systems (see for example, Ball 1980, 246 Jeffs and Lewis 2013, Jamieson et al. 2012). 


\section{Acknowledgements}

249 This project was funded by Le Fonds Européen Agricole pour le Développement Rural 250 (FEADER RBOU160118CR0260011 "Pérénité et développement de la filière cassis en

251 Bourgogne") and the Région Bourgogne-Franche-Comté in association with "Les acteurs du 252 cassis". We thank Manon Leon de Treverret for her technical support, Paul Simon who gave 253 us access to his blackcurrant orchards, Fabrice Ecalle (Chambre d'Agriculture 21), Olivier 254 Lenoir, three generations of the Family Lenoir, and all other blackcurrant growers for kindly 255 sharing their knowledge on past and present blackcurrant cultivation and encouraging this 256 study. We also thank Dr. Benjamin Normark from the University of Massachusetts, Dr. 257 Douglass Miller from the USDA, and Dr. Paul Amouroux from the Pontificia Universidad 258 Católica de Chile, who confirmed the taxonomic identification of P. pentagona. 


\section{References}

Awmack CS, Leather SR (2002) Host plant quality and fecundity in herbivorous insects. Annu Rev Entomol 47:817-844

Ball J. (1980) Development and fecundity of the White Peach Scale at two constant temperatures. Florida Entomol 63:188-194

Beardsley JWJ, Gonzalez RH (1975) The biology and ecology of armored scales. Annu Rev Entomol 20:47-73

Bennett F. (1956) Some parasites and predators of Pseudaulacaspis pentagona (Targ.) in Trinidad, B.W.I. Can Entomol 88:704-705

Bennett F., Brown S. (1958) Life history and sex determination in the Diaspine Scale, Pseudaulacaspis pentagona (Targ.) (Coccoidea). Can Entomol 90:317-324

Bottrell DG, Barbosa P, Gould F (1998) Manipulating natural enemies by plant variety selection and modification: A realistic strategy? Annu Rev Entomol 43:347-367. doi: 10.1146/annurev.ento.43.1.347

Boyero JR, Ruiz-López R, Rodríguez N, et al (2007) Varietal influence of orange trees on armoured scale insect fecundity (Hemiptera: Diaspididae). Int J Pest Manag 53:217-225. doi: 10.1080/09670870701289114

Dalstein MC, Guignebault P, Kreiter P (2016) Management of Pseudaulacaspis pentagona in French blackcurrant. In: Fernandez G., Hummer K. (eds) Acta Horticulturae, Proc. XI Int. Rubus and Ribes Symp. pp 445-450

Erkiliç LB, Uygun N (1997) Development time and fecundity of the white peach scale, Pseudaulacaspis pentagona, in Turkey. Phytoparasitica 25:9-16. doi: 10.1007/BF02981474

García-Morales M, Denno BD, Miller DR, et al (2016) ScaleNet: a literature-based model of scale insect biology and systematics. Database (Oxford) 2016:1-5. doi: 
Giongo L, Grisenti M, Eccher M, et al (2008) Horticultural and nutritional qualities of white, red and black currants. In: Acta Horticulturae, Proc. XI Int. Rubus and Ribes Symp. pp 167-171

Giron D, Dubreuil G, Bennett A, et al (2018) Promises and challenges in insect-plant interactions. Entomol Exp Appl 166:1-25. doi: 10.1111/eea.12679

Hanks LM, Denno RF (1994) Local adaptation in the armored scale insect Pseudaulacaspis Pentagona (Homoptera, Diaspididae). Ecology 75:2301-2310

Hanks LM, Denno RF (1993a) Natural enemies and plant water relations influence the distribution of an armored scale insect. Ecology 74:1081-1091. doi: 10.2307/1940478

Hanks LM, Denno RF (1993b) The White Peach Scale, Pseudaulacaspis pentagona (Targioni-Tozzetti) (Homoptera: Diaspidiae): Life history in Maryland, host plants, and natural enemies. Proc Entomol Soc Ofwashingt 95:79-98

Inbar M, Gerling D (2008) Plant-mediated interactions between whiteflies, herbivores, and natural enemies. Annu Rev Entomol 53:431-448. doi: 10.1146/annurev.ento.53.032107.122456

Jamieson MA, Trowbridge AM, Raffa KF, Lindroth RL (2012) Consequences of climate warming and altered precipitation patterns for plant-insect and multitrophic interactions. Plant Physiol 160:1719-1727. doi: 10.1104/pp.112.206524

Jarvis DI, Brown AHD, Cuong PH, et al (2008) A global perspective of the richness and evenness of traditional crop-variety diversity maintained by farming communities. Proc Natl Acad Sci 105:5326-5331. doi: 10.1073/pnas.0800607105

Jeffs CT, Lewis OT (2013) Effects of climate warming on host-parasitoid interactions. Ecol Entomol 38:209-218. doi: 10.1111/een.12026

Kerslake MF, Latrasse AG, Quere J Le (1989) Hydrocarbon chemotypes of some 

blackcurrant cultivars. J Sci Food Agric 47:43-51

310 Kosztarab M, Kozar F (1988) Scale insects of Central Europe. Budapest, 456p.

311 Kotowska AM, Cahill JF, Keddie BA (2010) Plant genetic diversity yields increased plant productivity and herbivore performance. J Ecol 98:237-245. doi: 10.1111/j.13652745.2009.01606.x

Kreiter P, Coquelet C, Thaon M (2002) La cochenille blanche du mûrier, principal ravageur des cassissiers en Région Rhône-Alpes. Bull mens Soc linn Lyon 71:251-25

Kreiter P, Marro J-P (1997) La cochenille du mûrier présente aussi dans la moitié nord de la France, importants foyers sur les arbres d'ornement. Phytoma - La défense des végétaux 491:58

Łabanowska BH, Pluta S (2010) Assessment of big bud mite (Cecidophyopsis ribis Westw.) infestation level of blackcurrant genotypes in the field. J Fruit Ornam Plant Res 18:283295

Le Quere J-L, Latrasse A (1990) Composition of the essential oils of blackcurrant buds. J Agric Food Chem 38:3-10

Moreau J, Desouhant E, Louâpre P, et al (2017) How host plant and fluctuating environments affect insect reproductive strategies? In: Advances in Botanical Research, Elsevier. pp

Moreau J, Villemant C, Benrey B, Thiéry D (2010) Species diversity of larval parasitoids of the European grapevine moth (Lobesia botrana, Lepidoptera: Tortricidae): The influence of region and cultivar. Biol Control 54:300-306. doi: 10.1016/j.biocontrol.2010.05.019

Nakagawa S, Cuthill IC (2007) Effect size, confidence interval and statistical significance: A

333 Pedata PA, Hunter MS, Godfray HCJ, Viggiani G (1995) The population dynamics of the 
white peach scale and its parasitoids in a mulberry orchard in Campania, Italy. Bull Entomol Res 85:531-539. doi: 10.1017/S0007485300033034

Pinheiro J, Bates D, Dedroy S, et al (2018) nlme: Linear and Nonlinear Mixed Effects Models, R package version 3.1-137

Pluta S, Broniarek-Niemiec A (2000) Field evaluation of resistance to white pine blister rust of selected blackcurrant genotypes in Poland. In: HortTechnology. pp 567-569

Price PW, Bouton CE, Gross P, et al (1980) Interactions among three trophic levels: influence of plants on interactions between insect herbivores and natural enemies. Annu Rev Ecol Syst 11:41-65. doi: 10.1146/annurev.es.11.110180.000353

R Core Team (2017) R: A language and environment for statistical computing. R Foundation for Statistical Computing, Vienna, Austria. URL https://www.R-project.org/

Rauleder H (2011) Antagonisten und prädatoren der maulbeerschildlaus Pseudaulacaspis pentagona (Targioni - Tozzetti, 1886)(Homoptera: Diaspididae) in Baden-Württemberg. Erwerbs-Obstbau 53:51-58. doi: 10.1007/s10341-011-0129-4

Vogelweith F, Dourneau M, Thiéry D, et al (2013) Geographical variation in parasitism shapes larval immune function in a phytophagous insect. Naturwissenschaften 100:1149-1161. doi: 10.1007/s00114-013-1119-1

Vogelweith F, Moreau J, Thiéry D, Moret Y (2015) Food-mediated modulation of immunity in a phytophagous insect: An effect of nutrition rather than parasitic contamination. $\mathbf{J}$ Insect Physiol 77:55-61. doi: 10.1016/j.jinsphys.2015.04.003

Wetzel WC, Kharouba HM, Robinson M, et al (2016) Variability in plant nutrients reduces insect herbivore performance. Nature 539:425-427. doi: 10.1038/nature20140

Yasuda S (1979) Microscopic observations on the external morphology of Pseudaulacaspis pentagona Targioni and on the portion of mulberry tissues inserted with the stylet. Japanese J Appl Entomol 23:61-68 
359 


\section{$360 \quad$ Figure legends}

361 Figure 1. Comparison of (A) density of shields, (B) density of alive females, and (C)

362 proportion of parasitized scales of overwintering $P$. pentagona females feeding on 'Noir de

363 Bourgogne' (NB) and 'Royal de Naples' (RN) blackcurrant varieties in Burgundy. Females

364 were collected in the basal (darkgrey) or the middle (lighgrey) segment of a blackcurrant

365 branch. Associated bars represent $95 \%$ confidence intervals of the means. $* \mathrm{P}<0.05 ; * \mathrm{P}<0.01$;

$366 * * * \mathrm{P}<0.001$.

367

368 Figure 2. (A) First anterior segment width [cm] of $P$. pentagona for overwintering females 369 feeding on 'Noir de Bourgogne' (NB) and 'Royal de Naples' (RN) blackcurrant varieties in

370 Burgundy. (B) Relationship between shield surface and first anterior segment width of the

371 females (NB-black line and circles: $y=-2.11+3.73 x, R^{2}=0.64$; $R N$-grey line and triangles: $y=-$ $\left.3720.79+2.47 x, R^{2}=0.49\right)$. Associated bars represent $95 \%$ confidence intervals of the means.

$373 * * * \mathrm{P}<0.001$. 


\section{$374 \quad$ Figures}

$375 \quad$ Figure 1
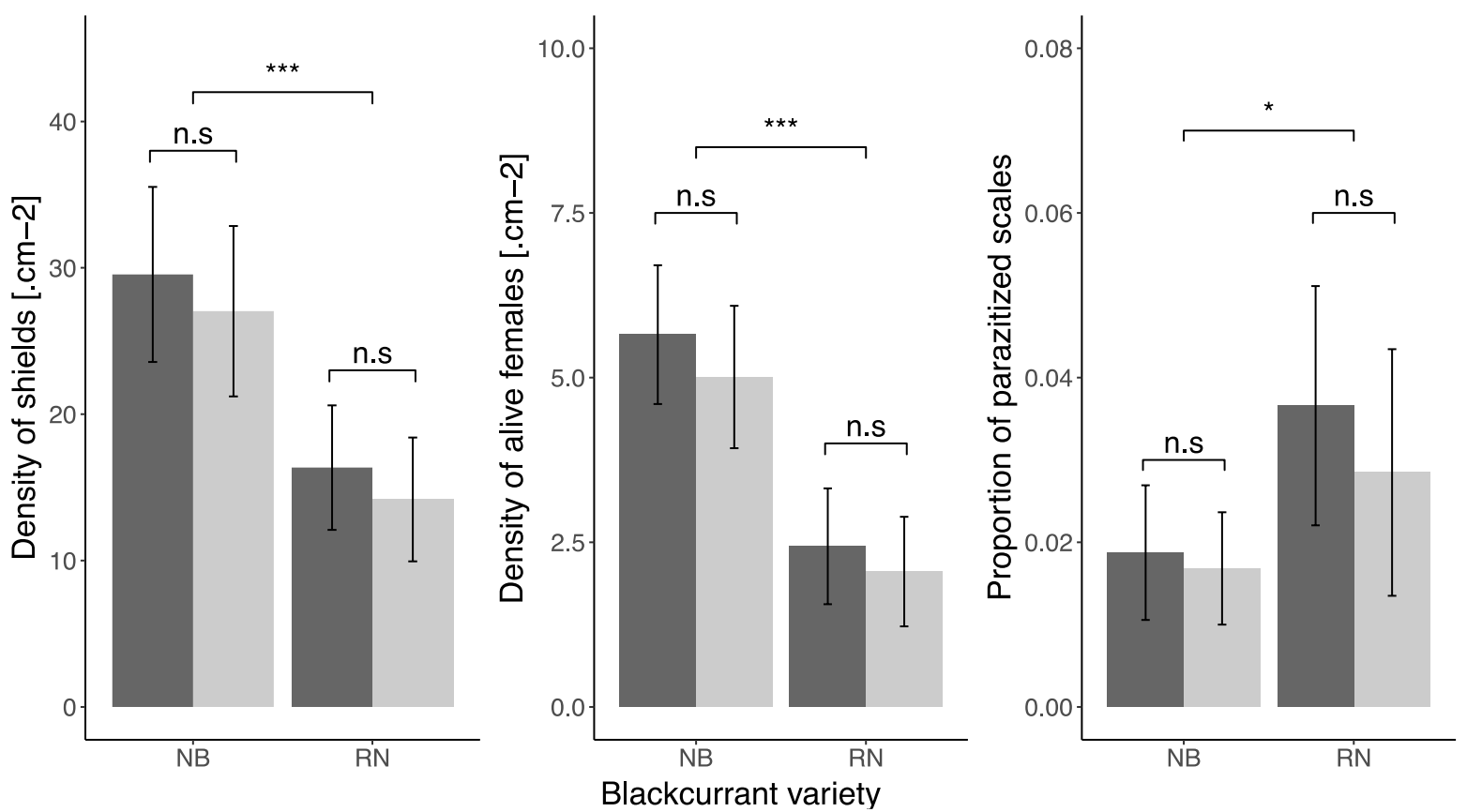
377 Figure 2
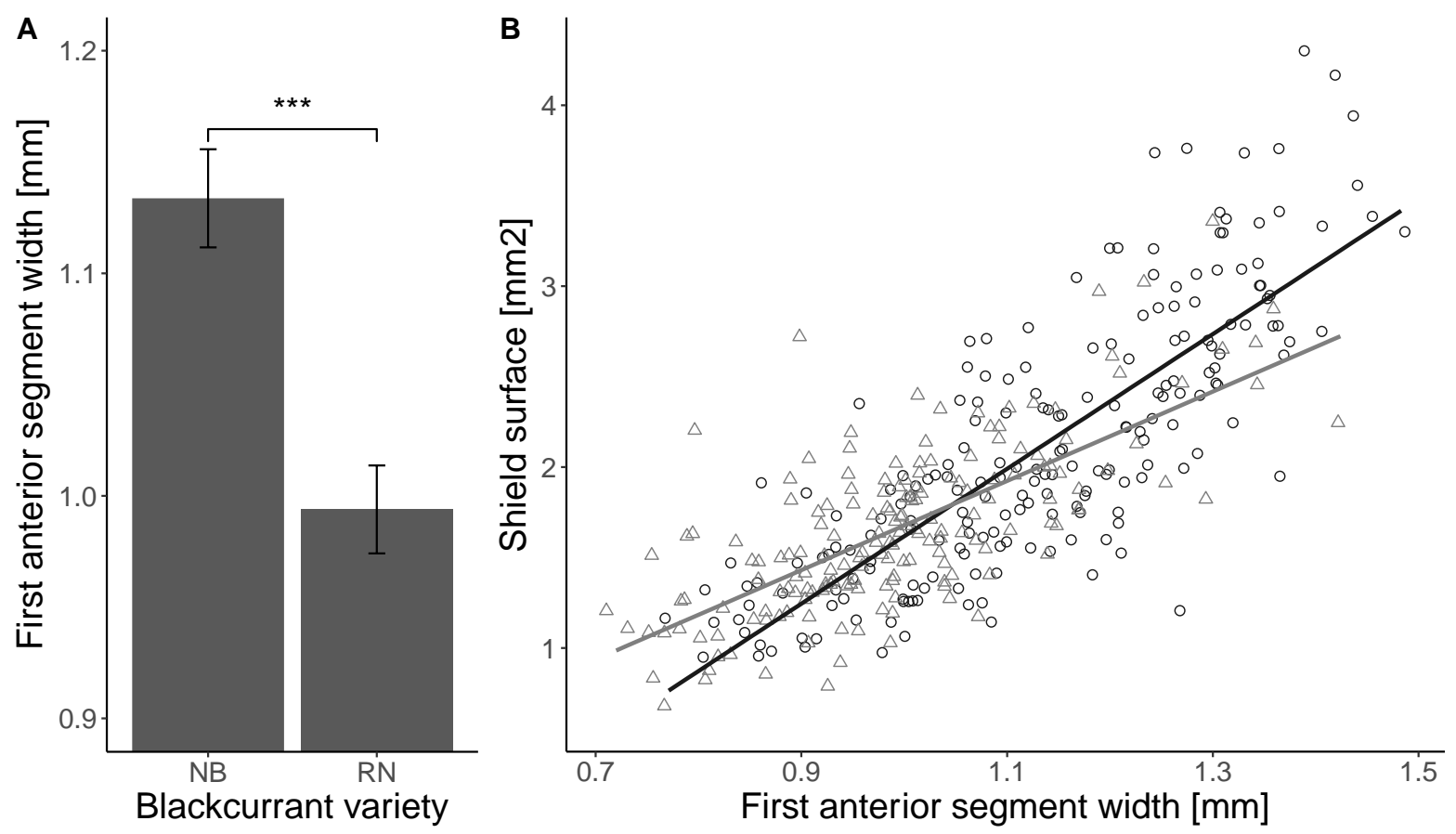